\title{
JNPH
}

Volume 7 No. 2 (Oktober 2019)

(C) The Author(s) 2019

\section{PENGARUH DZIKIR TERHADAP SKALA NYERI PADA IBU POST PARTUM SECTIO CAESAREA DI RSUD DR. M. YUNUS BENGKULU TAHUN 2019}

\author{
EFFECT OF ZIKIRS ON PAIN SCALE MOTHER POST PARTUM SECTIO \\ CAESAREA IN HOSPITAL DR. M. YUNUS BENGKULU IN 2019
}

\author{
TIARA VIVIYANI, DWI WULANDARI, ELSI RAHMADANI \\ FIKES UNIVED BENGKULU
}

\begin{abstract}
ABSTRAK
Sectio Caesarea di Indonesia persentasenya sebesar15,3\%, di Provinsi Bengkulu sectio caesar sebanyak 33.854 orang serta pada tahun 2018 sebanyak 393 orang di RSUD Dr. M.Yunus Bengkulu. Tujuan penelitian ini adalah untuk mengetahui pengaruh dzikir terhadap skala nyeri pada ibu post partum Sectio Caesarea di RSUD Dr. M. Yunus Bengkulu Tahun 2019. Metode yang digunakan adalah Quasi Eksperimen, pre two group test design with control group, data dikumpulkan melalui observasi skala nyeri sectio caesar pada 26 orang sampel dengan teknik accidental sampling. Hasil analisis Uji Univariat karakteristik ibu post partum yang melakukan sectio caesar yaitu 15 orang $(57,7 \%)$ berumur $<20$ tahun dan 12 orang $(46,2 \%)$ berpendidikan SMA. Rata-rata skala nyeri sebelum pada ibu post partum Sectio Caesarea pada kelompok intervensi 4,84 (Nyeri sedang) nyeri setelah 1,85 (Nyeri ringan). Rata-rata skala nyeri sebelum dan setelah pada ibu post partum Sectio Caesarea yaitu 5,00 (Nyeri sedang). Hasil bivariat yaitu Tidak ada pengaruh penurunan nyeri sebelum dan setelah pada ibu post partum Sectio Caesarea pada kelompok kontrol (tidak dilakukan dzikir). Ada pengaruh skala nyeri pada ibu post partum Sectio Caesarea pada kelompok intervensi (dilakukan dzikir) di RSUD Dr. M. Yunus Bengkulu Tahun 2019 dan tidak ada pengaruh penurunan nyeri sebelum dan setelah pada ibu post partum Sectio Caesarea pada kelompok kontrol (tidak dilakukan dzikir). Peneliti menyarankan pihak Rumah Sakit pihak petugas dapat menerapkan terapi dzikir dalam menurunkan nyeri post sectio caesar bukan hanya menjadi anjuran tapi melaksanakan intervensi terhadap anjuran yang selama ini diberikan.
\end{abstract}

Kata Kunci: Dzikir, Nyeri Sectio Caesar

\begin{abstract}
The percentage of Caesarea in Indonesia is $15.3 \%$, in Bengkulu Province there are 33,854 cesareans and in 2018 there are 393 people in RSUD Dr. M. Yunus Bengkulu. The purpose of this study was to determine the effect of dhikr on the scale of pain in postpartum Sectio Caesarean mothers in Dr. M. Yunus Bengkulu in 2019.The method used was Quasi Experiment, pre two group design test with control group, data were collected through observations of the caesarean section pain scale on 26 samples with accidental sampling technique.The results of the Univariate Test characteristic of post partum mothers who performed a caesarean section were 15 people $(57.7 \%)$ aged $<20$ years and 12 people $(46.2 \%)$ had a high school education. The average scale of pain before the post partum mother Sectio Caesarea in the intervention
\end{abstract}


group 4.84 (moderate pain) pain after 1.85 (mild pain). The average pain scale before and after the postpartum Sectio Caesarean mother is 5.00 (moderate pain). Bivariate results ie there was no effect of pain reduction before and after the post partum Sectio Caesarea in the control group (no dhikr). There is an effect on the scale of pain in post partum Sectio Caesarean mothers in the intervention group (performed dzikir) in Dr. M. Yunus Bengkulu In 2019 and there was no effect of pain reduction before and after the post partum mother Sectio Caesarea in the control group (no dhikr). Researchers suggest that the Hospital staff can implement dhikr therapy in reducing post sectio caesarean pain not only as a suggestion but to carry out an intervention against the recommendations that have been given.

\section{Keywords: Dhikr, Sectio Caesar Pain}

\section{PENDAHULUAN}

Setiap wanita menginginkan persalinannya berjalan lancar dan dapat melahirkan bayi dengan sempurna. Persalinan adalah suatu proses pengeluaran hasil konsepsi dari rahim ibu melalui jalan lahir atau dengan jalan lain, yang kemudian janin dapat hidup ke dunia luar (Rahayu 2016). Ada dua cara persalinan yaitu persalinan lewat vagina yang lebih dikenal dengan persalinan alami dan persalinan caesar atau section caesarea yaitu tindakan operasi untuk mengeluarkan bayi dengan melalui insisi pada dinding perut dan dinding rahim dengan syarat rahim dalam keadaan utuh serta berat janin diatas 500 gram (Maryunani, 2016).

World Health Organization (WHO) tahun 2016 menetapkan standar rata-rata sectio caesarea di sebuah negara adalah 5-15 $\%$ per 1000 kelahiran di dunia dan angka persalinan dengan Sectio Caesarea sekitar $10 \%$ sampai $15 \%$ dari semua proses persalinan. Di negara maju seperti Britania Raya angka kejadian Sectio Caesarea sebesar 20\% (Sihombing, 2017). Berdasarkan data dari Kemenkes RI (2016) angka kejadian Sectio Caesarea di Indonesia persentasenya sebesar $15,3 \%$, diatas standar yang dikeluarkan WHO, yaitu di rumah sakit pemerintah rata-rata persalinan dengan Sectio Caesarea sebesar 11\%, sementara di Rumah Sakit Swasta bisa lebih dari 30\% (Pusdatin, 2017).

Berdasarkan profil Dinas Kesehatan Provinsi Bengkulu jumlah persalinan sectio caesar sebanyak 33.854 orang dengan jumlah persalinan tertinggi di Kota Bengkulu sebanya 6.566 orang dan jumlah persalinan terendah di Kabupaten Lebong sebanyak 919 orang (Dinkes Provinsi Bengkulu, 2017)

Persalinan section caesarea juga memiliki dampak yaitu mengalami nyeri skala tinggi selama 24 jam pertama, hal ini terjadi karena tubuh belum dapat menyesuaikan terhadap respon nyeri (Kuswandari, 2016). Persalinan sectio caesar juga menyebabkan keterbatasan gerak tubuh ibu sehingga proses penyembuhan luka akan semakin lama dan juga menimbulkan nyeri, perdarahan, infeksi dan luka kandung kemih (Fauzi, 2013). Nyeri adalah suatu pengalaman sensori dan emosional yang tidak menyenangkan akibat dari kerusakan jaringan yang bersifat subjektif. Keluhan sensori yang dinyatakan sebagai pegal, linu, ngilu, dapat dianggap sebagai modalitas nyeri. Nyeri pada persalinan sectio caesar juga disebabkan oleh insisi pada persalinan sectio caesar (Muttaqin, 2009).

Manajemen nyeri mempunyai beberapa tindakan atau prosedur baik secara farmakologis maupun non farmakologis. Prosedur secara farmakologis dilakukan dengan pemberian Non-opioid mencakup asetaminofen dan obat antiinflamatory drug/NSAID, Opioid: secara tradisional dikenal dengan narkotik dan koanalgesik (adjuvants) atau analgesik yaitu untuk mengurangi atau menghilangkan rasa nyeri, akan tetapi juga memiliki dampak buruk bagi kesehatan seperti gangguan saluran pencernaan, gangguan ginjal, reaksi alergi dan gangguan hati (Zakiyah, 2014). 
Sedangkan secara non farmakologis dapat dilakukan dengan cara relaksasi, distraksi, stimulasi kuteneus dan herbal. Salah satu jenis relaksai yaitu melakukan meditasi dan dzikir (Yuliatun, 2014).

Saat ini telah dikembangkan terapi nonfarmakologi berdasarkan Islam, yaitu dzikir. Dzikir adalah rangkaian kalimat yang diucapkan dalam rangka untuk mengingat Allah, serta usaha untuk selalu menjalankan segala perintah-Nya dan menjauhi segala larangan-Nya (Winarko, 2014). Secara fisiologis, dzikir akan menghasilkan beberapa efek medis dan psikologis yaitu akan membuat seimbang kadar serotonin dan norepineprin di dalam tubuh. Hal tersebut merupakan morfin alami yang bekerja di dalam otak yang dapat membuat hati dan pikiran merasa tenang setelah berdzikir (Hidayat, 2014). Allah berfirman "Orangorang yang beriman dan hati mereka menjadi tentram dengan mengingat Allah SWT (dzikrullah). Ingatlah, hanya dengan mengingat Allahlah hati menjadi tentram" (QS. Ar-Ra'du: 29).

Relaksasi merupakan teknik yang dilakukan agar tercapai keadaan relaks. Teknik relaksasi lain mencakup meditasi, yoga, latihan relaksasi otot progresif dan dzikir (Zakiyah, 2014). Metode dzikir sangat efektif dibandingkan metode yoga dan meditasi karena saat persalinan SC sebagian besar ibu belum berani duduk dan berdiri, sehingga mendekatkan diri dengan tuhanlah pilihan yang tepat, karena melibatkan keyakinan dalam hubungan dengan sesuatu yang lebih tinggi, berkuasa, memiliki kekuatan mencipta, dan bersifat ketuhanan, atau memiliki energ $\mathrm{i}$ yang tidak terbatas (Kuswandari, 2016).

Penelitian yang dilakukan oleh Kuswandari (2016) menyebutkan bahwa terdapat pengaruh dzikir terhadap penurunan skala nyeri pada ibu post SC, karena dzikir akan membuat seseorang merasa tenang sehingga kemudian menekan kerja sistem saraf simpatis dan mengaktifkan kerja sistem saraf parasimpatis dengan nilai $p=0,000$, penelitian ini dilakukan 6 jam setelah post SC dan pada penelitian ini tidak ada kelompok kontrol. Penelitian yang dilakukan oleh Soliman \& Muhamed (2013) menyebutkan bahwa dzikir dapat mengurangi nyeri post pembedahan abdomen. Dari hasil penelitian setelah dilakukan pre-test, kemudian diberikan intervensi, didapatkan hasil terdapat penurunan skala nyeri pada kelompok intervensi dengan nilai $p=0,004$ $(p<0,05)$, pada penelitian ini intervensi dilakukan pada 6 jam setelah post SC.

Berdasarkan data dari beberapa Rumah Sakit di Kota Bengkulu tahun 2018 jumlah persalinan sectio caesar spinal yaitu di RSUD Kota Bengkulu sebanyak 30 orang dan Zainul Arifin TK IV Bengkulu sebanyak 898 orang. Berdasarkan data yang diperoleh dari rekam medik RSUD Dr. M. Yunus Bengkulu jumlah persalinan sectio caesar mengalami peningkatan setiap tahun yaitu pada tahun 2016 jumlah persalinan Sectio Caesarea berjumlah 217 orang, pada tahun 2017 jumlah persalinan Sectio Caesarea 205 orang dan mengalami peningkatan yang signifikan pada tahun 2018 sebanyak 393 orang (RSUD Dr. M. Yunus Bengkulu, 2018).

Berdasarkan studi awal yang dilakukan oleh peneliti pada tanggal 08 Desember sampai dengan 12 Desember tahun 2018 terdapat 5 responden ibu post partum sectio caesar, 2 diantaranya mengatakan saat mengalami nyeri post SC pada responden mengkonsumsi obat sedangkan 3 responden yang lainnya melakukan relaksasi dan berdzikir untuk mengurangi nyeri yang mereka rasakan disertai bantuan obat farmakologis dari Rumah Sakit.

Berdasarkan latar belakang inilah maka peneliti tertarik untuk melakukan penelitian "Pengaruh dzikir terhadap skala nyeri pada ibu post partum Sectio Caesarea di RSUD Dr. M. Yunus Bengkulu Tahun 2019”.

Rumusan masalah penelitian adalah"Bagaimana Pengaruh dzikir terhadap skala nyeri pada ibu post partum Sectio Caesarea di RSUD Dr. M. Yunus Bengkulu Tahun 2019"?. Tujuan Penelitian adalah untuk mengetahui pengaruh dzikir terhadap 
skala nyeri pada ibu post partum Sectio Caesarea di RSUD Dr. M. Yunus Bengkulu Tahun 2019.

\section{METODE PENELITIAN}

Penelitian ini merupakan penelitian kuantitative dengan metode quasi experiment menggunakan pendekatan two group test design with control group/ Penelitian ini dilakukan di RSUD Dr. M. Yunus Bengkulu Tahun 2019. Waktu penelitian dimulai pada bulan 17 Mei-17 Juni 2019.Populasi dalam penelitian ini adalah seluruh pasien yang melakukan sectio caesar RSUD Dr. M. Yunus Bengkulu Tahun 2018 sebanyak 393 orang, sampel dalam penelitian ini sampel sebanyak 26 orang yang terdiri dari 13 responden pada kelompok kasus dan 13 responden pada kelompok kontrol dengan teknik accidental . pengumpulan data menggunakan data primer dan sekunder

\section{HASIL PENELITIAN}

\section{Analisis Univariat}

a. Karakteristik Responden

Tabel 1. Karakteristik ibu post partum Sectio Caesarea

\begin{tabular}{ccc}
\hline Variabel & Frekuensi & $\begin{array}{c}\text { Persentase } \\
(\mathbf{\%})\end{array}$ \\
\hline Umur & & \\
\hline$<20$ tahun & 15 & 57,7 \\
\hline $20-35$ tahun & 11 & 42,3 \\
\hline Total & $\mathbf{2 6}$ & $\mathbf{1 0 0 , 0}$ \\
\hline Pendidikan & & \\
\hline SMP & 10 & 38,5 \\
\hline SMA & 12 & 46,2 \\
\hline SI & 4 & 15,4 \\
\hline Total & $\mathbf{2 6}$ & $\mathbf{1 0 0 , 0}$ \\
\hline
\end{tabular}

Berdasarkan tabel 1 diketahui bahwa karakteristik ibu post partum di RSUD Dr. M. Yunus yang melakukan sectio caesar diketahui bahwa sebanyak 15 orang $(57,7 \%$ berumur $<20$ tahun dan 11 orang $(42,3 \%)$ berumur 20-35 tahun. Dari 26 rsponden diketahui sebanyak 10 orang $(38,5 \%)$ berpendidikan SMP, 12 orang $(46,2 \%)$ berpendidikan SMA dan 4 orang $(15,4 \%)$ berpendidikan SI.Skala nyeri sebelum dan setelah pada ibu post partum Sectio Caesarea pada kelompok intervensi

Tabel 2. Nyeri sebelum dan setelah pada ibu post partum Sectio Caesarea pada kelompok intervensi di RSUD Dr. $M$. Yunus Bengkulu

\begin{tabular}{cc}
\hline $\begin{array}{c}\text { Nyeri Sectio Caesar } \\
\text { Kelompok Intervensi }\end{array}$ & Mean \\
\hline Pre Test & 4.84 \\
\hline Post Test & 1,85 \\
\hline
\end{tabular}

Berdasarkan Tabel 2 di atas diketahui bahwa rata-rata nyeri sebelum diberikan perlakuan pada ibu post partum Sectio Caesarea pada tingkat nyeri 4,84 (Nyeri sedang), sedangkan nilai rata-rata diberikan perlakuan pada kelompok intervensi dengan tingkat nyeri 1,85 (Nyeri ringan) di RSUD Dr. M. Yunus Bengkulu .

a. Skala nyeri sebelum dan setelah pada ibu post partum Sectio Caesarea pada kelompok kontrol

Tabel 3. Nyeri sebelum dan setelah pada ibu post partum Sectio Caesarea pada kelompok kontrol di RSUD Dr. M. Yunus Bengkulu

\begin{tabular}{cc}
\hline $\begin{array}{c}\text { Nyeri Sectio Caesar } \\
\text { Kelompok Kontrol }\end{array}$ & Mean \\
\hline Pre Test & 5.00 \\
\hline Post Test & 5.00 \\
\hline
\end{tabular}

Berdasarkan Tabel 3 di atas diketahui bahwa nyeri setelah pada ibu post partum Sectio Caesarea pada kelompok kontrol dengan rata-rata 5,00 (Nyeri sedang) di RSUD Dr. M. Yunus Bengkulu.

\section{Analisa Bivariat}

\section{a. Pengaruh dzikir terhadap nyeri sebelum}


dan setelah pada kelompok Intervensi dan Kontrol

Tabel 4. Pengaruh dzikir terhadap nyeri sebelum dan setelah dilakukan dzikir pada ibu post partum Sectio Caesarea pada kelompok intervensi dan kontrol di RSUD Dr. M. Yunus Bengkulu Tahun 2019

\begin{tabular}{|c|c|c|c|c|c|}
\hline Variabel & Variabel & Mean & $S D$ & $\begin{array}{c}C I \\
95 \%\end{array}$ & $\begin{array}{c}P \\
\text { Value }\end{array}$ \\
\hline \multirow{2}{*}{ Intervensi- } & $\begin{array}{c}\text { Nyeri } \\
\text { Sebelum }\end{array}$ & 4.84 & 0.98 & $\begin{array}{c}4,24- \\
5,44 \\
\end{array}$ & \multirow{2}{*}{0,001} \\
\hline & $\begin{array}{l}\text { Nyeri } \\
\text { Setelah }\end{array}$ & 1,85 & 0.80 & $\begin{array}{l}1,36- \\
2,33\end{array}$ & \\
\hline \multirow{2}{*}{ Kontrol } & $\begin{array}{c}\text { Nyeri } \\
\text { Sebelum }\end{array}$ & 5.00 & 0.70 & $\begin{array}{c}4,57- \\
5,42\end{array}$ & \multirow{2}{*}{$-1,000$} \\
\hline & $\begin{array}{c}\text { Nyeri } \\
\text { Setelah }\end{array}$ & 5.00 & 0.70 & $\begin{array}{c}4,57- \\
5,42\end{array}$ & \\
\hline
\end{tabular}

Berdasarkan tabel 4 diketahui nilai mean nyeri sebelum dilakukan dzikir yaitu 4,84 (nyeri sedang) dengan $\mathrm{SD}=0,98$ serta $\mathrm{CI}$ $95 \%=4,24-5,44$ dan setelah dilakukan dzikir nyeri yang dirasakan responden yaitu 1,85 (nyeri ringan) dengan $\mathrm{SD}=0.80$ serta $\mathrm{CI}$ $95 \%=1,36-2,33$. Dari hasil uji statistik wilcoxon didapatkan nilai ( $p$ value $=0,001)$, maka dapat disimpulkan bahwa ada pengaruh penurunan nyeri sebelum dan setelah dilakukan dzikir pada ibu post partum Sectio Caesarea pada kelompok intervensi (dilakukan dzikir) di RSUD Dr. M. Yunus Bengkulu Tahun 2019.

Pada kelompok kontrol nilai mean nyeri sebelum yaitu 5,000 (nyeri sedang), $\mathrm{SD}=0,70711$ dengan CI 95\%=4,57-5,42 dan setelah yaitu 5,00 (nyeri ringan) dengan $\mathrm{SD}=0,70$ dan CI 95\%=4,57-5,42. Dari hasil uji statistik wilcoxon didapatkan nilai ( $p$ value $=1,000)$, maka dapat disimpulkan bahwa tidak ada pengaruh penurunan nyeri sebelum dan setelah pada ibu post partum Sectio Caesarea pada kelompok kontrol (tidak dilakukan dzikir) di RSUD Dr. M. Yunus Bengkulu Tahun 2019.

\section{b. Pengaruh Dzikir terhadap Nyeri Sectio Caesar antar Kelompok Intervensi dan}

\section{Kontrol}

Tabel 5. Pengaruh dzikir terhadap nyeri pada ibu post partum Sectio Caesarea antar kelompok intervensi dan kelompok kontrol di RSUD Dr. M. Yunus Bengkulu Tahun 2019

\begin{tabular}{|c|c|c|c|c|c|}
\hline \multirow[t]{2}{*}{ Variabel } & \multicolumn{2}{|c|}{ Pre-Test } & \multicolumn{2}{|c|}{ Post-Test } & \multirow{2}{*}{$\begin{array}{c}P \\
\text { Value }\end{array}$} \\
\hline & Mean & SD & Mean & SD & \\
\hline $\begin{array}{c}\text { Nyeri } \\
\text { Kelompok } \\
\text { Intervensi }\end{array}$ & 4.84 & 0.98 & 1,85 & 0.80 & \\
\hline $\begin{array}{c}\text { Nyeri } \\
\text { Kelompok } \\
\text { Kontrol }\end{array}$ & 5.00 & 0.70 & 5.00 & 0.70 & 0 \\
\hline
\end{tabular}

Berdasarkan Tabel 5 diketahui bahwa selisih mean pada kelompok intervensi dan kontrol yaitu sebelum intrvensi nilai mean 4,84 dan setelah intervensi mengalami penurunan nyeri yaitu 1,84 , sedangkan pada kelomok kontrol yaitu sebelum intrvensi nilai mean 5.00 dan setelah intervensi tidak mengalami penurunan nyeri yaitu dengan mean skala tetap yaitu 5. 00. Dari hasil uji statistik dengan uji Mann Whitney nilai signifikansi $p=0,000 \leq 0,05$, maka Ho ditolak sehingga terdapat perbedaan skala nyeri pada ibu post partum Sectio Caesarea pada kelompok intervensi dan kelompok kontrol di RSUD Dr. M. Yunus Bengkulu Tahun 2019.

\section{PEMBAHASAN}

1. Gambaran Karakteristik Ibu Post Partum yang Mengalami Sectio Caesar

a. Umur

Berdasarkan hasil penelitian diketahui bahwa umur ibu post partum di RSUD Dr. M. Yunus yang melakukan sectio caesar yaitu sebanyak 15 orang $(57,7 \%)$ berumur $<20$ tahun dan sebanyak 11 orang $(42,3 \%)$ berumur 20-35 tahun. Hal ini menunjukan bahwa mayoritas responden berusia $<20$ tahun yang sectio caesar. Didukung teori Manuaba (2014) menyebutkan bahwa ibu yang melahirkan dengan umur $>35$ tahun 
lebih, termasuk berisiko melahirkan SC, demikian juga dengan ibu yang berusia $<20$ tahun. Bila usia ibu saat melahirkan $<20$ tahun, maka kecenderungan dilakukan persalinan secara SC dapat dipertimbangkan juga, karena organ-organ kandungan saat umur $<20$ tahun belum matang.

Hasil penelitian ini juga sependapat dengan penelitian Maria tahun 2016 dengan judul indikasi persalinan sectio caesar berdasarkan umur dan paritas Di RS DKT Gubeng Pojok Surabaya menyebutkan bahwa mayoritas persalinan sectio caesar berusia $<20$ tahun yaitu $83 \%$.

\section{b. Pendidikan}

Hasil penelitian ini juga dietahui bahwa pendidikan ibu post partum sectio caesar di RSUD Dr. M.Yunus Bengkulu yaitu 10 orang $(38,5 \%)$ berpendidikan SMP, 12 orang $(46,2 \%)$ berpendidikan SMA dan 4 orang $(15,4 \%)$ berpendidikan SI. Pendidikan adalah usaha sadar dan terencana untuk mewujudkan suasana belajar dan proses pembelajaran agar peserta didik secara aktif mengembangkan potensi dirinya untuk memiliki kekuatan spiritual keagamaan, pengendalian diri, kepribadian, kecerdasan, akhlak mulia, serta keterampilan yang diperlukan dirinya, masyarakat, Bangsa dan Negara (Wawan, 2010).

Hasil penelitian ini sejalan dengan penelitian Lestari tahun 2016 dari hasil analisis univariat didapatkan responden yang bersalin dengan sectio caesar berpendidikan tinggi (D3 dan Sarjana) 17 orang (42,2 \%) sedangkan responden yang berpendidikan rendah (SMA, SMP, SD) 19 orang (58,7 \%).

\section{Gambaran skala nyeri sebelum dan setelah pada ibu post partum Sectio Caesarea pada kelompok intervensi}

Hasil penelitian diketahui bahwa ratarata nyeri sebelum pada ibu post partum Sectio Caesarea pada kelompok intervensi yaitu 4,84 (Nyeri sedang) di RSUD Dr. M. Yunus Bengkulu. Hasil penelitian diketahui bahwa rata-rata nyeri setelah pada ibu post partum Sectio Caesarea pada kelompok intervensi yaitu 1,85 (Nyeri ringan) di RSUD Dr. M. Yunus Bengkulu, hal ini menunjukkan terdapat penurunan skala nyeri sebelum dan setelah pada kelompok intervensi. Nyeri yang dapat ditolerir oleh pasien adalah rentang 1-3 atau nyeri ringan (Gerbershagen,Rothaug, Kalkman, \& Meissner, 2011). Nyeri post SC tentunya juga mengganggu berlangsungnya laktasi sehingga akan berakibat berkurangnya nutrisi pada bayi, dan berkurangnya bonding attachment antara ibu dan bayi (Alexander et al, 2010).

Persalinan caesar atau section caesarea yaitu tindakan operasi untuk mengeluarkan bayi dengan melalui insisi pada dinding perut dan dinding rahim dengan syarat rahim dalam keadaan utuh serta berat janin diatas 500 gram. Proses persalinan yang melakukan insisi tersebut dapat menimbulkan nyeri (Maryunani, 2016). Nyeri adalah pengalaman sensori yang tidak menyenangkan, unsur utama yang harus ada untuk disebut sebagai nyeri adalah rasa tidak menyenangkan. Tanpa unsur itu tidak dapat dikategorikan sebagai nyeri, walaupun sebaliknya, semua yang tidak menyenangkan tidak dapat disebut sebagai nyeri. Pada skala nyeri sedang (4-6) Secara obyektif klien mendesis, menyeringai, dapat menunjukkan lokasi nyeri, dapat mendeskripsikannya, dapat mengikuti perintah dengan baik. (Zakiyah, 2014).

Dzikir akan membuat seseorang merasa tenang sehingga kemudian menekan kerja sistem saraf simpatis dan mengaktifkan kerja sistem saraf parasimpatis. Allah berfirman "Orang-orang yang beriman dan hati mereka menjadi tentram dengan mengingat Allah SWT (dzikrullah). Ingatlah, hanya dengan mengingat Allahlah hati menjadi tentram" (QS. Ar-Ra'du: 29). Relaksasi dan doa (prayer) menggunakan keterpaduan dan hubungan (interconnectedness) tubuh dan jiwa (mind and body) untuk perbaikan kesehatan, dalam arti lain pikiran dapat dilatih untuk menginisiasi saraf parasimpatik 
memulai perbaikan secara natural untuk menurunkan metabolisme tubuh yang terlalu tinggi, denyut nadi, kecepatan perfasan, tekanan darah, dan ketegangan otot sehingga kembali normal sehingga memicu relaksasi dan kesembuhan (Lloyd \& Dunn 2007).

Sejalan dengan penelitian Sutrisno (2011) tentang dzikir telah dilakukan dalam mengurangi tingkat kecemasan pasien sebelum operasi, dengan skala minimum dan maximum sebelum pada kelompok yang diberikan intervensi pada kelompok kontrol skala nyeri yang dirasakan responden pada skala nyeri sedang (5-6). Penelitian yang dilakukan Rizky (2016) menyebutkan bahwa mean sebelum pada kelompok intervensi adalah 5,96 dan setelah dilakukan intervensi mengalami penurunan menjadi 4,05.

\section{Gambaran rata-rata skala nyeri sebelum dan setelah pada ibu post partum Sectio Caesarea pada kelompok kontrol}

Hasil penelitian diketahui bahwa ratarata skala nyeri setelah pada ibu post partum Sectio Caesarea pada kelompok kontrol yaitu 5,00 (Nyeri sedang), hal ini menunjukkan bahwa nyeri yang dirasakan mayoritas responden pada skala nyeri sedang. Hasil penelitian diketahui bahwa arta-rata skala nyeri setelah pada ibu post partum Sectio Caesarea pada kelompok kontrol dengan mean 5,00 (Nyeri sedang), hal ini menunjukkan bahwa tidak ada perubahan skala nyeri.

Secara garis besar, nyeri terjadi akibat dari sensitasi pada perifer yang akan dilanjutkan pada sensitasi sentral. Mekanisme timbulnya nyeri didasari oleh proses multipel yaitu nosisepsi, sensitisasi perifer, perubahan fenotip, sensitisasi sentral, eksitabilitas ektopik, reorganisasi struktural, dan penurunan inhibisi. Nyeri pada post SC diakibatkan dari robeknya lapisan kulit dan jaringan di bawahnya akibat pembedahan. Nosisepsi adalah mekanisme yang menimbulkan nyeri nosiseptif dan terdiri dari proses transduksi, konduksi, transmisi, modulasi, dan persepsi. Nyeri terjadi akibat dari sensitasi pada perifer yang akan dilanjutkan pada sensitasi sentral. Nyeri pada post SC sensitasi perifer berasal dari robeknya lapisan kulit dan jaringan di bawahnya akibat pembedahan (Vascopoulos \& Lema, 2010).

Sejalan dengan penelitian Kuswandari (2016) menyebutkan bahwa tidak ada perubahan terhadap skala nyeri pada kelompok kontrol yaitu tingkat nyeri paling banyak saat pre-test adalah skala 5, nyeri paling tinggi adalah skala 8 dan nyeri yang paling rendah adalah skala 4. Sedangkan skala nyeri yang paling banyak pada saat post-test adalah pada skala 6 yaitu sebanyak 6 responden (30\%), yang paling tinggi adalah skala 8 yaitu sebanyak 1 orang, dan nyeri paling rendah adalah skala 2 sebanyak 1 orang $(5 \%)$.

\section{Pengaruh dzikir terhadap nyeri sebelum dan setelah pada kelompok Intervensi}

Hasil penelitian diketahui nilai mean nyeri sebelum dilakukan dzikir yaitu 4,84 (nyeri sedang) dengan $\mathrm{SD}=0,98$ dan setelah dilakukan dzikir nyeri yang dirasakan responden yaitu 1,85 (nyeri ringan) dengan $\mathrm{SD}=0.80$. Dari hasil uji statistik wilcoxon didapatkan nilai ( $p$ value $=0,001)$, maka dapat disimpulkan bahwa ada pengaruh penurunan nyeri sebelum dan setelah dilakukan dzikir pada ibu post partum Sectio Caesarea pada kelompok intervensi (dilakukan dzikir) di RSUD Dr. M. Yunus Bengkulu Tahun 2019.

Didukung teori Yuliatun (2014) menyatakan bahwa manajemen nyeri mempunyai beberapa tindakan atau prosedur baik secara farmakologis maupun non farmakologis. Prosedur secara farmakologis dilakukan dengan pemberian Non-opioid mencakup asetaminofen dan obat antiinflamatory drug/NSAID, Opioid: secara tradisional dikenal dengan narkotik dan koanalgesik (adjuvants) atau analgesik yaitu untuk mengurangi atau menghilangkan rasa nyeri. Sedangkan secara non farmakologis dapat dilakukan dengan cara relaksasi, 
distraksi, stimulasi kuteneus dan herbal. Salah satu jenis relaksai yaitu melakukan meditasi dan dzikir.

Saat ini telah dikembangkan terapi nonfarmakologi berdasarkan Islam, yaitu dzikir. Dzikir adalah rangkaian kalimat yang diucapkan dalam rangka untuk mengingat Allah, serta usaha untuk selalu menjalankan segala perintah-Nya dan menjauhi segala larangan-Nya (Winarko, 2014). Secara fisiologis, dzikir akan menghasilkan beberapa efek medis dan psikologis yaitu akan membuat seimbang kadar serotonin dan norepineprin di dalam tubuh. Hal tersebut merupakan morfin alami yang bekerja di dalam otak yang dapat membuat hati dan pikiran merasa tenang setelah berdzikir (Hidayat, 2014). Allah berfirman "Orangorang yang beriman dan hati mereka menjadi tentram dengan mengingat Allah SWT (dzikrullah). Ingatlah, hanya dengan mengingat Allahlah hati menjadi tentram" (QS. Ar-Ra'du: 29).

Sejalan dengan penelitian yang dilakukan oleh Kuswandari (2016) menyebutkan bahwa terdapat pengaruh dzikir terhadap penurunan skala nyeri pada ibu post SC, karena dzikir akan membuat seseorang merasa tenang sehingga kemudian menekan kerja sistem saraf simpatis dan mengaktifkan kerja sistem saraf parasimpatis yang menimbulkan efek penurunan nyeri.

Sejalan juga dengan penelitian yang dilakukan oleh Rudyana \& Bangun (2013) di bangsal bedah RSUP Dr. Hasan Sadikin Bandung, mengenai Dzikir (Asmaul Husna). Hasil dari penelitian tersebut setelah dilakukan uji dengan Mann-Whitney pada kelompok intervensi didapatkan $p=0,001$ $(p<0,05)$ sehingga dapat disimpulkan bahwa terdapat penurunan nyeri setelah dilakukan Dzikir pada pasien post Laparotomi yang mengalami nyeri.

\section{Pengaruh dzikir terhadap nyeri sebelum dan setelah pada kelompok Kontrol}

Hasil penelitian diketahui nilai mean nyeri sebelum dilakukan dzikir yaitu 5,00 (nyeri sedang) dengan $\mathrm{SD}=0,70$ dan setelah dilakukan dzikir nyeri yang dirasakan responden yaitu 5,00 (nyeri ringan) dengan $\mathrm{SD}=0,70$. Dari hasil uji statistik wilcoxon didapatkan nilai ( $p$ value $=1,000)$, maka dapat disimpulkan bahwa tidak ada pengaruh penurunan nyeri sebelum dan setelah dilakukan dzikir pada ibu post partum Sectio Caesarea pada kelompok intervensi (dilakukan dzikir) di RSUD Dr. M. Yunus Bengkulu Tahun 2019.

Persalinan caesar atau section caesarea yaitu tindakan operasi untuk mengeluarkan bayi dengan melalui insisi pada dinding perut dan dinding rahim dengan syarat rahim dalam keadaan utuh serta berat janin diatas 500 gram. Proses persalinan yang melakukaninsisi tersebut dapat menimbulkan nyeri (Maryunani, 2016). Nyeri adalah pengalaman sensori yang tidak menyenangkan, unsur utama yang harus ada untuk disebut sebagai nyeri adalah rasa tidak menyenangkan. Tanpa unsur itu tidak dapat dikategorikan sebagai nyeri, walaupun sebaliknya, semua yang tidak menyenangkan tidak dapat disebut sebagai nyeri. Pada skala nyeri sedang (4-6) Secara obyektif klien mendesis, menyeringai, dapat menunjukkan lokasi nyeri, dapat mendeskripsikannya, dapat mengikuti perintah dengan baik. (Zakiyah, 2014)

Menurut teori Vascopoulos \& Lema (2010) Nyeri pada post SC sensitasi perifer berasal dari robeknya lapisan kulit dan jaringan di bawahnya akibat pembedahan, nyeri yang dapat ditolerir yaitu skala 1-3. Pada pasien mengalami nyeri pada level 4 atau lebih dari 4, setelah diberikan obat analgetik tidak mengalami penurunan diakibatkan saraf-saraf yang menghantarkan stimulus nyeri ke otak sehingga perlu melakukan terapi lain seperti terapi nonfarmakologi, nyeri tersebut akan mengalami proses transduksi (Potter \& Perry, 2010). Transduksi terjadi ketika stimulus berupa suhu, kimia atau mekanik diubah menjadi energi listrik. Transduksi dimulai dari perifer, ketika stimulus mengirimkan impuls yang melewati serabut saraf nyeri 
perifer yang terdapat di panca indra, maka akan menimbulkan potensial aksi. Setelah proses transduksi selesai, kemudian terjadi proses transmisi impuls nyeri. Kerusakan sel mengakibatkan pelepasan neurotransmitter eksitatori seperti protaglandin, bradikinin, kalium, histamin dan substansi P (Kyranou \& Puntillo, 2012). Substansi neurotransmitter yang peka terhadap nyeri yang terdapat di sekitar serabut nyeri yang terdapat di cairan ekstraseluler, menyebarkan "pesan" adanya nyeri dan menyebabkan inflamasi atau peradangan (Potter \& Perry, 2010).

Sejalan dengan penelitian Sodikin (2012) bahwa distraksi auditori dengan dzikir (Asmaul Husna) sangat efektif menurunkan intensitas skala nyeri post operasi, sedangkan pada kelompok kontrol tidak ada penurunan intensitas nyeri setelah jang waktu yang telah ditetapkan $(\mathrm{p}=1,000)$.

\section{Pengaruh dzikir terhadap skala nyeri pada ibu post partum Sectio Caesarea antar kelompok intervensi dan kelompok kontrol di RSUD Dr. M. Yunus Bengkulu Tahun 2019}

Hasil penelitian diketahui selisih mean pada kelompok intervensi dan kontrol yaitu sebelum intrvensi nilai mean 4,84 dan setelah intervensi mengalami penurunan nyeri yaitu 1,85 , sedangkan pada kelomok kontrol yaitu sebelum intrvensi nilai mean 5.00 dan setelah intervensi tidak mengalami penurunan nyeri yaitu dengan mean skala tetap yaitu 5.00. Dari hasil uji statistik dengan uji Mann Whitney nilai signifikansi $p=0,000 \leq 0,05$, maka Ho ditolak sehingga terdapat pengaruh skala nyeri pada ibu post partum Sectio Caesarea pada kelompok intervensi dan kelompok kontrol di RSUD Dr. M. Yunus Bengkulu Tahun 2019.

Hasil penelitian ini menunjukkan bahwa dengan terapi dzikir pasien akan mengalami kenyamanan dan ketenangan sehingga nyeri yang dirasakan berkurang, berbanding pada kelompok kontrol setelah selang waktu tertentu tetap tidak mengalami perubahan. Didukung teori Mahfani (2014) bahwa dzikir akan membuat seseorang merasa selalu di dalam lindungan dan bimbingan Allah dalam menjalani hidup, sehingga membuat seseorang tetap bersemangat dalam menjalani hidup tanoa takut akan rintangan yang akan dihadapinya karena Allah senantiasa bersamanya.

Secara isiologis, dzikir akan menghasilkan beberapa efek medis dan psikologis yaitu akan membuat seimbang kadar serotonin dan norepineprin di dalam tubuh. Hal tersebut merupakan morfin alami yang bekerja di dalam otak yang dapat membuat hati dan pikiran merasa tenang setelah berdzikir (Hidayat, 2014).

Didukung penelitian yang dilakukan

oleh Soliman \& Muhamed (2013) menyebutkan bahwa dzikir dapat mengurangi nyeri post pembedahan abdomen. Dari hasil penelitian setelah dilakukan pre-test, kemudian diberikan intervensi, didapatkan hasil terdapat penurunan skala nyeri pada kelompok intervensi dengan nilai $p=0,004$ $(p<0,05)$ dan terdapat pengaruh yang signifikan skala nyeri antara kelompok kontrol dan intervensi pada pasien post SC dengan nilai $p=0,000$.

Sependapat dengan penelitian Rudyana (2014) menyebutkan bahwa dari analisis data melalui dua tahapan, yaitu univariat untuk melihat distribusi frekuensi dan bivariat untuk melihat pengaruh. Hasil uji Mann-Whitney didapatkan $(p=0,001 ; \alpha=0,05) \quad$ yang berarti ada perbedaan penurunan intensitas nyeri yang signifikan antara sesudah diberikan intervensi dzikir (Asmaul Husna) pada kelompok intervensi dengan sesudah pada kelompok kontrol. Sebagai kesimpulan dari penelitian ini adalah adanya pengaruh dari dzikir (Asmaul Husna) terhadap skala intensitas nyeri pasien post operasi laparatomi. Maka disarankan bagi rumah sakit menggunakan dzikir (Asmaul Husna) sebagai distraksi auditori non farmakologi untuk menurunkan intensitas nyeri, khususnya pasien post operasi laparatomi. 


\section{KESIMPULAN}

1. Karakteristik ibu post partum di RSUD Dr. M. Yunus yang melakukan sectio caesar yaitu sebagian besar atau 15 orang $(57,7 \%)$ berumur $<20$ tahun dan hampir setengah responden 12 orang $(46,2 \%)$ berpendidikan SMA.

2. Rata-rata skala nyeri sebelum pada ibu post partum Sectio Caesarea pada kelompok intervensi yaitu 4,84 (Nyeri sedang) nyeri setelah pada ibu post partum Sectio Caesarea pada kelompok intervensi yaitu 1,85 (Nyeri ringan) di RSUD Dr. M. Yunus Bengkulu.

3. Rata-rata skala nyeri sebelum dan setelah pada ibu post partum Sectio Caesarea pada kelompok kontrol yaitu 5,00 (Nyeri sedang) di RSUD Dr. M. Yunus Bengkulu

4. Ada pengaruh skala nyeri pada ibu post partum Sectio Caesarea pada kelompok intervensi (dilakukan dzikir) di RSUD Dr. M. Yunus Bengkulu Tahun 2019 dan tidak ada pengaruh penurunan nyeri sebelum dan setelah pada ibu post partum Sectio Caesarea pada kelompok kontrol (tidak dilakukan dzikir),

5. Ada perbedaan skala nyeri pada ibu post partum Sectio Caesarea antar kelompok intervensi dan kelompok kontrol di RSUD Dr. M. Yunus Bengkulu Tahun 2019

\section{SARAN}

Diharapkan kepada masyarakat dapat menjadikan hasil penelitian ini sebagai panduan dalam menghadapi rasa nyeri pada ibu post partum Sectio Caesarea.

\section{DAFTAR PUSTAKA}

Fauzi. (2013). Operasi Caesar Masalah dan Solusinya. Jakarta: Puspswara

Kuswandari (2016). Pengaruh Dzikir Untuk Mengurangi Skala Nyeri Pada Ibu Post Sectio Caesarea (SC). diunduh dari http://repository.umy.ac.id/ bitstream/handle/123456789/5841/11.\% 20Naskah\%. diakases pada tanggal 2
Desember 2018.

Mahfani. 2014. Efektivitas Dzkrullah terhadap Penurunan Kecemasan dan Nyeri Persalinan Kala I Fase Aktif Ibu Primigravida. Diunduh dari http://repository.unissula.ac.id/. Di akses pada tanggal 10 Desember 2018

Maryunani, A. (2016). Manajemen Kebidanan Terlengkap. Jakarta Timur: CV. Trans Info Media

Muttaqin. (2009). Asuhan Kepeawatan Perioperatif. Jakarta: Selemba Medika.

Potter \& Perry. (2010). Fundamental on Nursing 3th edition. Jakarta: Salemba Medika

Pusdatin. (2017). Pusat Data Informasi Kesehatan Ibu dan Anak. Jakarta. Kemenkes RI

Rahayu., S. (2016). Panduan Praktis Asuhan Kebidanan Fisiologis. Jakarta: CV. Tran Info Media. 2016

Rs. Zainul Arivin TK IV Bengkulu. 2018. Profil Data Di Rs Zainul Arivin TK IV Bengkulu. Bengkulu

RSUD Dr. M. Yunus Bengkulu. (2018). Profil Data Di RSUD Dr. M. Yunus Bengkulu. Bengkulu

RSUD Kota Bengkulu. (2018). Profil Data di RSUD Kota Bengkulu. Kota Bengkulu

Rudyana \& Bangun. (2013). Pengaruh Dzikir (Asmaul Husna) Terhadap Skala Intensitas Nyeri Pasien Post Operasi Laparatomi Di Ruang Bedah RSUP Dr. Hasan Sadikin Bandung. Diunduh dari http://repository.

stikesayani.ac.id/index.php/Jurnal Kartika/article/view/142/104. Diakses pada tanggal 3 Desember 2018.

Sihombing. 2017. Kematian Ibu. [diunduh 16 Desember 2018] tersedia dari dari https://www.

https://media.neliti.com/media /publications

Soliman, H., \& Mohamed, S. (2013). Effects of Zikr Meditation and Jaw Relaxation on Postoperative Pain, Anxiety and Physiologic Response of Patients Undergoing Abdominal Surgery. 
Journal of Biology, Agriculture and Healthcare.

Vascopoulos \& Lema. (2010). Pengaruh Dzikir (Asmaul Husna) Terhadap Skala Intensitas Nyeri Pasien Post Operasi Laparatomi Di Ruang Bedah RSUP Dr. Hasan Sadikin Bandung. Diunduh dari http://repository.stikesayani.

ac.id/index.php/Jurnal

Kartika/article/view/142/104. Diakses pada tanggal 3 Desember 2018

Winarko, S. A. (2014). Dzikir-Dzikir Peredam Stres.Depok: Mutiara Allamah Utama

Yuliatun. (2014). Manajemen Nyeri. Jakarta: Bhuana Ilmu Populer

Zakiyah. (2014). Nyeri Konsep dan Penatalaksanaan dalam Praktik Keperawatan Berbasis Bukti. Jakarta: Selemba Medika. 2014 